\title{
PENGARUH MODEL CREATIVE PROBLEM SOLVING (CPS) TERHADAP KEMAMPUAN BERPIKIR KRITIS MATEMATIS PADA MATERI RELASI DAN FUNGSI
}

\author{
Sonta Maria \\ Universitas Katolik Santo Thomas, Medan; \\ sontamanik60@gmail.com
}

\begin{abstract}
Abstrak. Tujuan penelitian ini adalah untuk mengetahui pengaruh model pembelajaran Creative Problem Solving (CPS) terhadap kemampuan berpikir kritis matematis siswa pada materi relasi dan fungsi dan respon siswa terhadap model pembelajaran CPS. Penelitian ini merupakan penelitian eksperimen kuasi (quasi experiment). Hasil penelitian diperoleh persamaan regresi $\mathrm{Y}=62.1621+15.7094 \mathrm{X}$ dengan koefisien determinasi $23 \%$ yangmana menunjukkan bahwa terdapat pengaruh positif. Nilai rata-rata kemampuan berpikir kritis matematis siswa yang mengikuti pembelajaran dengan model CPS sebesar 77.87, sementara pembelajaran ekspositori sebesar 62.16. Analisis respon siswa terhadap model pembelajaran CPS diperoleh: (1) Sebesar $97.3 \%$ menyatakan tertarik terhadap model pembelajaran CPS dan $2.7 \%$ menyatakan tidak tertarik; (2) Sebesar $98.2 \%$ menyatakan ada manfaat yang didapatkan siswa dengan menggunakan model pembelajaran CPS dan $1.8 \%$ menyatakan bahwa tidak ada manfaat yang didapat; (3) Sebesar $90.74 \%$ menyatakan tidak ada kendala yang dialami selama proses pembelajaran dengan menggunakan model pembelajaran CPS dan $9.26 \%$ menyatakan mengalami kendala; (4) Sebesar $96.22 \%$ berharap bahwa model pembelajaran CPS digunakan dalam proses pembelajaran dan $3.78 \%$ tidak berharap digunakan. Jadi, disimpulkan bahwa respon siswa sangat positif terhadap model pembelajaran CPS karena persentase yang menyatakan persetujuan yaitu $95.62 \%$ lebih besar daripada yang menyatakan ketidaksetujuan yaitu $4.38 \%$.
\end{abstract}

Kata Kunci. Creative Problem Solving, berpikir kritis

Abstract. The purpose of this study was to determine the effect of the Creative Problem Solving (CPS) learning model on students' critical thinking skills in the material relations and functions and student responses to the CPS learning model. This research is a quasi-experiment. The results of the study obtained a regression equation $Y=62.1621+15.7094 X$ with a coefficient of determination of $23 \%$ which indicates that there is a positive influence. The average value of

Cartesius: Jurnal Pendidikan Matematika Vol. 1, No. 1

CProdi Pendidikan Matematika Universitas Katolik Santo Thomas 
mathematical critical thinking abilities of students who take part in the learning with the CPS model is 77.87, while expository learning is 62.16. Analysis of student responses to the CPS learning model was obtained: (1) $97.3 \%$ expressed interest in the CPS learning model and 2.7\% expressed no interest; (2) A total of $98.2 \%$ stated that there were benefits obtained by students using the CPS learning model and $1.8 \%$ stated that there were no benefits obtained; (3) A total of $90.74 \%$ stated that there were no obstacles experienced during the learning process using the CPS learning model and 9.26\% stated that they experienced problems; (4) $96.22 \%$ expect that the CPS learning model is used in the learning process and $3.78 \%$ do not expect to be used. So, it was concluded that the student response was very positive towards the CPS learning model because the percentage that stated the agreement was $95.62 \%$ greater than the one who expressed disagreement namely $4.38 \%$.

Keywords. Creative Problem Solving, critical thinking

\section{PENDAHULUAN}

Bidang pendidikan merupakan salah satu bidang yang mempunyai pengaruh yang penting dalam menciptakan generasi penerus bangsa yang cerdas dan berkarakter. Hal ini sejalan dengan bunyi Undang-Undang Nomor 20 Tahun 2003 tentang Sistem Pendidikan Nasional yang berbunyi bahwa pendidikan adalah usaha sadar dan terencana untuk mewujudkan suasana dan proses pembelajaran agar siswa secara aktif mengembangkan potensi dirinya dan memiliki kekuatan spiritual keagamaan, pengendalian diri, kepribadian, kecerdasan, akhlak mulia, serta keterampilan yang diperlukan oleh dirinya, masyarakat, bangsa dan negara [1]. Pembelajaran di sekolah merupakan salah satu kegiatan mencerdaskan kehidupan bangsa [2]. Kecerdasan berkaitan dengan kemampuan berpikir individu. Kemampuan berpikir dapat dilatih melalui pembelajaran matematika dikarenakan matematika berhubungan dengan masalah-masalah yang mempunyai tingkat kerumitan lebih tinggi dari mata pelajaran lainnya. Olehkarena itu banyak siswa kurang berminat belajar matematika dibanding belajar mata pelajaran lainnya.

Berdasarkan Peraturan Menteri Pendidikan Nasional Nomor 22 Tahun 2006, disebutkan bahwa matematika merupakan ilmu universal yang mendasari perkembangan teknologi modern dan berperan penting dalam berbagai disiplin ilmu dalam mengembangkan daya pikir manusia. Mata pelajaran

Cartesius: Jurnal Pendidikan Matematika Vol. 1, No. 1

CProdi Pendidikan Matematika Universitas Katolik Santo Thomas 
matematika diberikan kepada semua peserta didik mulai dari sekolah dasar untuk membekali peserta didik dengan kemampuan berpikir logis, analisis, sistematis, kritis, dan kreatif [3].

Berpikir tidak terlepas dari aktivitas manusia, karena berpikir merupakan ciri yang membedakan antara manusia dengan makhluk hidup lainnya. Mengingat pentingnya matematika khususnya dalam kehidupan sehari-hari, maka pembelajaran matematika merupakan hal yang penting untuk diperhatikan. Dalam proses pembelajaran matematika di sekolah diharapkan guru dapat membekali peserta didik dengan kemampuan berpikir kritis dalam memecahkan masalah yang dialami dalam kehidupan sehari-hari [4].

Berpikir kritis merupakan salah satu proses berpikir tingkat tinggi yang memungkinkan manusia menganalisa masalah berdasarkan data yang relevan sehingga dapat mencari kemungkinan pemecahan masalah dan pengambilan keputusan yang terbaik. Seseorang yang berpikir kritis cenderung peka terhadap informasi atau situasi yang sedang dihadapinya, memiliki kemampuan mendalam, penalaran dan kemampuan menyimpulkan yang tepat [5]. Kemampuan berpikir kritis yang baik sangat perlu dan urgen untuk dikembangkan terlebih pada masa sekarang yang penuh dengan permasalahan-permasalahan atau tantangan-tantangan hidup dalam membentuk sikap-perilaku yang rasional [6]. Oleh karena itu kemampuan berpikir kritis merupakan salah satu tuntutan yang harus dipenuhi pada pembelajaran saat ini [7].

Ketika seorang sedang berpikir kritis, maka dia sedang melakukan sebuah aktivitas mental dalam memecahkan masalah yang dihadapi. Seperti yang dikemukakan oleh Ennis bahwa indikator kemampuan berpikir kritis meliputi memberikan penjelasan sederhana (elementary clarification), membangun keterampilan dasar (basic support), menyimpulkan (inference), memberikan penjelasan lanjut (advances clarification), hingga akhirnya mengatur strategi dan taktik yang tepat (strategy and tactics) [8].

Kemampuan berpikir kritis siswa mempengaruhi prestasi dan hasil belajar siswa. Hasil studi Programme for International Student Assesment (PISA) pada 
tahun 2015, Indonesia hanya menduduki peringkat ke-69 dari 76 negara. Hal ini menunjukkan bahwa kemampuan siswa SMP khususnya dalam bidang matematika masih di bawah standar internasional. Hal serupa juga dapat dilihat dari hasil Ujian Nasional (UN) yang selalu jadi tolak ukur keberhasilan siswa. Pada pelaksanaan Ujian Nasional (UN) SMP Tahun 2016, pelajaran matematika mengalami penurunan terbesar. Perubahannya dari 56.28 kini nilainya menjadi 50.24. Terjadi penurunan sebesar 6.04 poin.

Rendahnya aspek berpikir kritis siswa juga dapat dilihat dari proses siswa menyelesaikan soal. Berikut contoh penyelesaian siswa dalam menjawab soal cerita faktorisasi suku aljabar yang menunjukkan bahwa siswa masih kesulitan dalam menyelesaikan soal cerita yang diberikan sebagai berikut: (1) Anton, Andi, dan Jackie adalah tiga orang kakak-beradik. Umur Anton adalah 10 tahun, umur Andi lebih muda dari umur Jackie dan lebih tua dari umur Anton. Sedangkan umur Jackie dua kali lebih tua dari umur Anton. Selisih umur Andi dengan umur Anton Adalah 5 tahun. Dari pernyataan tersebut, berapakah umur Andi? Buat langkah-langkah penyelesaiannya dan buktikan apakah jawaban kalian benar! (2) Ani memiliki uang di ATM sebanyak Rp. 5.000.000,-. Mula-mula Ani membeli 5 tas dan 2 jam tangan. 1 tas seharga Rp. 200.000,- dan 1 jam tangang seharga Rp. 180.000,-. Jika Ani ingin membeli 3 tas dan 3 jam tangan lagi, maka berapakh sisa uang Ani sekarang? Buatlah kesimpulannya!

Berdasarkan analisis hasil jawaban diperoleh data bahwa kemampuan berpikir kritis siswa masih rendah. Dari 30 siswa, 12 siswa (40\%) yang mampu memahami soal, melaksanakan proses yang benar dan mendapat hasil atau solusi yang benar. Sebanyak 3 orang (10 \%) siswa yang memahami soal dan menggunakan strategi yang benar, tetapi ada sedikit salah perhitungan. Siswa yang memahami soal, melaksanakan prosedur yang benar, memberikan jawaban yang benar tetapi salah dalam struktur atau perhitungan sebanyak 6 orang (20\%), dan selebihnya siswa kesulitan dalam membuat model serta menyelesaikan model matematikanya.

Rendahnya hasil belajar siswa dari data yang ditemukan baik secara internasional, nasional, dan lokal dapat terjadi karena siswa terbiasa hanya 
menghafal rumus, dan kurang mampu menggunakan konsep yang terkandung dalam rumus tersebut. Kurangnya keterampilan berpikir kritis siswa sehingga pembelajaran kurang efektif. Siswa terbiasa lebih pasif dan bergantung pada guru sehingga tidak memiliki kesempatan untuk mengembangkan pengetahuan dan kemampuan berpikirnya. Terciptanya komunikasi satu arah dalam pembelajaran yang mana guru lebih aktif dalam memberikan informasi sedangkan siswa hanya mendengarkan penjelasan dari guru. Dari kondisi-kondisi yang telah dijabarkan di atas, maka dapat disimpulkan bahwa respon siswa dalam proses pembelajaran kurang aktif.

Pada umumnya yang ditemukan di lapangan khususnya Sekolah Lanjutan Tingkat Pertama (SLTP) adalah seperti guru yang kurang kreatif dalam menggunakan model dan metode pembelajaran. Guru hanya menggunakan metode ceramah sehingga pembelajaran itu bersifat monoton dan terkesan membosankan. Hal itu mengakibatkan siswa kurang terlatih dalam pemecahan masalah dan berpikir kritis.

Keberhasilan proses pembelajaran siswa tergantung bagaimana guru menggunakan model pembelajaran yang tepat. Salah satu model pembelajaran yang baik diterapkan sebagai upaya dalam melatih siswa untuk memecahkan masalah serta berpikir kritis adalah model pembelajaran Creative Problem Solving (CPS). Model pembelajaran CPS dilakukan dengan pemusatan pada pengajaran dan keterampilan memecahkan masalah yang diikuti dengan penguatan keterampilan [9].

Berdasarkan hasil penelitian yang dilakukan sebelumnya oleh Marwin Tamrin (2012) tentang efektivitas model pembelajaran CPS dalam pembelajaran materi limit fungsi aljabar disimpulkan bahwa model pembelajaran CPS baik untuk diterapkan dalam meningkatkan kemampuan berpikir kritis dan hasil belajar. Hasil penelitian menunjukkan bahwa terdapat perbedaan hasil belajar siswa antara kelas $X_{1}$ dan $X_{2}$ sehingga dapat dikatakan penggunaan model pembelajaran Creative Problem Solving (CPS) efektif dalam meningkatkan hasil belajar siswa pada materi limit fungsi aljabar dengan nilai thitung $=5.6445>$ tabel $=2.977$ [10] . 
Berdasarkan penjelasan sebelumnya bahwa model pembelajaran CPS merupakan salah satu solusi untuk meningkatkan kemampuan berpikir kritis siswa. Bertitik tolak dari hal tersebut maka dilakukan penelitian dengan tentang Pengaruh Model Pembelajaran Creative Problem Solving (CPS) Terhadap Kemampuan Berpikir Kritis Matematis Pada Materi Relasi dan Fungsi.

\section{METODE}

Penelitian ini merupakan penelitian yang menggunakan pendekatan kuantitatif. Metode penelitian yang digunakan dalam penelitian ini adalah metode eksperimen kuasi. Penelitian ini dilaksanakan di SMP Kavri Talun Kenas pada semester ganjil Tahun Ajaran 2017/2018. Desain penelitian yang dilakukan dalam penelitian ini adalah pretest-posttest control group design. Dalam hal ini peneliti menggunakan tes menganai materi prasyarat dari materi relasi dan fungsi pada siswa sebagai tes awal (pretest) yaitu sebelum menggunakan model Creative Problem Solving (CPS) dan memberikan tes mengenai materi relasi dan fungsi setelah menggunakan model Creative Problem Solving (CPS) sebagai tes akhir (posttest).

Populasi penelitian ini adalah seluruh kelas VII SMP Kavri Talun Kenas Tahun Ajaran 2017/2018. Yang berjumlah 74 siswa. Teknik pengambilan sampel yang digunakan dalam penelitian ini adalah teknik pengambilan sampel secara acak atau simple random sampling. Dalam penelitian ini terpilih siswa kelas VIII-1 sebagai kelas eksperimen sebanyak 37 siswa dan siswa kelas VIII-2 sebagai kelas kontrol sebanyak 37 siswa. Siswa dalam kelas eksperimen memperoleh perlakuan dibelajarkan dengan model pembelajaran Creative Problem Solving dan kelas control memperoleh perlakuan dibelajarkan dengan pembelajaran ekspositori (biasa).

Teknik pengumpulan data yang digunakan adalah teknik tes dan non tes. Teknik tes meliputi tes kemampuan berpikir kritis matematis untuk materi prasyarat pretest) dan materi posttest yang terdiri dari 6 soal berbentuk uraian. Kemampuan berpikir kritis yang diukur dari soal-soal yang diberikan meliputi: (1) Elementary clarification (memberikan penjelasan 
sederhana); (2) Basic support (membangun keterampilan dasar); (3) Inference (menyimpulkan); dan (4) Strategies and tactics (strategi dan taktik).

Teknik non tes dalam penelitian ini adalah menggunakan angket respon siswa yang bertujuan untuk mengetahui tanggapan siswa terhadap kegiatan pembelajaran matematika dengan menggunakan model Creative Problem Solving (CPS). Pernyataan-pernyataan pada angket respon siswa berupa pernyataan positif dan negatif berkenaan dengan aspek yang akan diukur yang disusun dalam bentuk skala Likert. Adapun aspek yang akan diukur berdasarkan pada indikator respon siswa terhadap model pembelajaran yang dimodifikasi dari Kusuma dan Aisyah (2012) yaitu (1) Ketertarikan siswa terhadap model pembelajaran; (2) Manfaat yang didapatkan siswa dengan menggunakan model pembelajaran tersebut; (3) Kendala yang dialami siswa selama proses pembelajaran menggunakan model tersebut; (4) Harapan dan saran siswa terhadap model pembelajaran. Hasil angket respon siswa dianalisis dengan persentase dari setiap jawaban siswa dengan menggunakan rumus yang dimodifikasi Arifin (dalam Purwanto, dkk. 2016: 54) sebagai berikut:

$$
P=\frac{\sum K}{\sum N} \times 100 \%
$$

Keterangan:

$P=$ Persentase respon siswa

$K$ = Siswa yang memilih option

$N=$ Jumlah siswa (responden)

Adapun kriteria respon siswa yang dimodifikasi dari Khabibah (dalam Martha, Inneke Rheyza, \& Rini Setianingsih, 2014: 100) dapat dilihat pada tabel berikut:

Tabel 1. Kriteria Respon Siswa

\begin{tabular}{ccl}
\hline No. & $\begin{array}{c}\text { Persentase Respon Siswa } \\
(\%)\end{array}$ & \multicolumn{1}{c}{ Kategori } \\
\hline 1. & $\mathrm{RS} \geq 85 \%$ & Sangat positif \\
2. & $70 \% \leq \mathrm{RS}<85 \%$ & Positif \\
3. & $50 \% \leq \mathrm{RS}<70 \%$ & Kurang Positif \\
4. & $\mathrm{RS} \leq 50 \%$ & Tidak positif \\
\hline
\end{tabular}

Cartesius: Jurnal Pendidikan Matematika Vol. 1, No. 1

CProdi Pendidikan Matematika Universitas Katolik Santo Thomas 
Variabel yang digunakan dalam penelitian ini adalah model pembelajaran Creative Problem Solving (CPS) sebagai variabel bebas (X) dan kemampuan berpikir kritis matematis sebagai variabel terikat (Y). Sebelum dilakukan uji hipotesis, terlebih dahulu dilakukan uji prasyarat yang meliputi uji normalitas dan homogenitas. Dalam pengujian hipotesis penelitian akan diuji dengan menggunakan analisis regresi linier sederhana dan korelasi.

\section{HASIL DAN PEMBAHASAN}

Penelitian ini menggunakan model pembelajaran Creative Problem Solving (CPS) pada kelas eksperimen yaitu kelas VIII-1 dan pembelajaran ekspositori pada kelas kontrol yaitu kelas VIII-2. Data dideskripsikan dalam penelitian ini adalah hasil tes kemampuan berpikir kritis matematis siswa. Hasil tes yang dideskripsikan untuk mengetahui informasi tentang kemampuan siswa sebelum (pretest) dan sesudah (posttest) dilakukan pembelajaran. Secara umum dideskripsikan kedua kelompok data untuk kemampuan berpikir kritis matematis siswa pada tabel berikut:

Tabel 2. Deskrispi Pretes dan Postes Kemampuan Berpikir Kritis Matematis Siswa Kelas Eksperimen dan Kelas Kontrol

\begin{tabular}{lcccc}
\hline \multirow{2}{*}{ Nilai } & \multicolumn{2}{c}{ Kelas Eksperimen } & \multicolumn{2}{c}{ Kelas Kontrol } \\
\cline { 2 - 5 } & Pretes & Postes & Pretes & Postes \\
\hline $\mathrm{N}$ & 37 & 37 & 37 & 37 \\
Terendah & 31.25 & 56.25 & 25 & 37.5 \\
Tertinggi & 81.25 & 100 & 81.25 & 87.5 \\
Rata-Rata & 60.30 & 77.87 & 59.79 & 62.16 \\
Standart & 15.18 & 14.55 & 15.27 & 14.65 \\
Deviasi & & 211.79 & 233.38 & 214.73 \\
Varians & 230.50 & & & \\
\hline
\end{tabular}

Dari hasil penelitian diperoleh rata-rata kelas eksperimen yang menggunakan model Creative Problem Solving (CPS) adalah sebesar 77.87 dan nilai rata-rata kelas control yang menggunakan pembelajaran ekspositori adalah sebesar 62.16 .

Sebelum melakukan uji homogenitas varians, terlebih dahulu peneliti melakukan uji normalitas data. Dalam penelitian ini, uji normalitas yang 
digunakan adalah uji Liliefors. Adapun hasil perhitungan normalitas untuk data pretes dengan uji Liliefors dapat dilihat dari tabel berikut:

Tabel 3. Hasil Uji Normalitas Pretes Kemampuan Berpikir Kritis Matematis Siswa Kelas Eksperimen dan Kelas Kontrol

\begin{tabular}{lcccc}
\hline \multirow{2}{*}{ Soal } & \multicolumn{2}{c}{ Eksperimen } & \multicolumn{2}{c}{ Kontrol } \\
\cline { 2 - 5 } Pretes & Lhitung & Ltabel & Lhitung & Ltabel \\
Keterangan & 0.10 & 0.14 & 0.13 & 0.14 \\
Lhitung $<$ Ltabel & $\begin{array}{l}\text { Lhitung }<\text { Ltabel } \\
\text { Dota pretes berdistribusi } \\
\text { normal }\end{array}$ & $\begin{array}{l}\text { Data pretes berdistribusi } \\
\text { normal }\end{array}$ \\
\hline
\end{tabular}

Adapun hasil perhitungan normalitas untuk data postes dengan uji Liliefors dapat dilihat pada tabel berikut:

Tabel 4. Hasil Uji Normalitas Prostes Kemampuan Berpikir Kritis Matematis Siswa Kelas Eksperimen dan Kelas Kontrol

\begin{tabular}{ccccc}
\hline \multirow{2}{*}{ Soal } & \multicolumn{2}{c}{ Eksperimen } & \multicolumn{2}{c}{ Kontrol } \\
\cline { 2 - 5 } Postes & 0.08 & Ltabel & Lhitung & Ltabel \\
\hline Keterangan & 0.14 & 0.11 & 0.14 \\
Lhitung $<$ Ltabel & $\begin{array}{l}\text { Lhitung }<\text { Ltabel } \\
\text { Data postes berdistribusi } \\
\text { normal }\end{array}$ & $\begin{array}{l}\text { Data postes berdistribusi } \\
\text { normal }\end{array}$ \\
\hline
\end{tabular}

Setelah diketahui bahwa kedua kelompok sampel pada penelitian ini dinyatakan berasal dari data yang berdistribusi normal, maka analisis dilanjutkan dengan uji homogenitas varians kedua kelompok. Adapun uji homogenitas yang digunakan dalam penelitian ini adalah uji Fisher (uji F). Hasil perhitungan uji homogenitas pretes di kelas eksperimen dan kelas control dapat dilihat pada tabel berikut:

Tabel 5. Hasil Uji Homogenitas Pretes Kemampuan Berpikir Kritis Matematis Siswa Kelas Eksperimen dan Kelas Kontrol

\begin{tabular}{|l|c|c|c|c|c|l|}
\hline \multicolumn{2}{|c|}{ Kelompok } & Varians & $\begin{array}{c}\text { Banyak } \\
\text { Siswa }\end{array}$ & F hitung & $F_{\text {tabel }}$ & Simpulan \\
\hline Eksperimen & Pretes & 230.50 & 37 & 1.02 & 1.76 & $\begin{array}{l}\mathrm{H}_{0} \\
\text { diterima }\end{array}$ \\
\hline Kontrol & Pretes & 233.85 & 37 & 1.02 & \\
\hline
\end{tabular}

Cartesius: Jurnal Pendidikan Matematika Vol. 1, No. 1

CProdi Pendidikan Matematika Universitas Katolik Santo Thomas 
Berdasarkan hasil uji homogenitas pada tabel tersebut diketahui nilai varians pretes kelas eksperimen sebesar 230.50 dan nilai pretes kelas control sebesar 233.85. Perhitungan uji homogenitas kelompok eksperimen dan kelompok control diperoleh $\mathrm{F}_{\text {hitung }}=1.02$ sedangkan nilai $\mathrm{F}_{\text {tabel }}=1.76$ dengan $\alpha=0.05$ dan dk pembilang $=37-1=36$ (untuk varians terbesar) dan $\mathrm{dk}$ penyebut $=37$ $1=36$ (untuk varians kecil). Dengan demikian diketahui bahwa nilai $F_{\text {hitung }} \leq$ $\mathrm{F}_{\text {tabel }}$ maka $\mathrm{H}_{0}$ diterima dan $\mathrm{H}_{a}$ ditolak. Hal ini berarti data memiliki varians yang sama atau homogen.

Setelah diketahui data berdistribusi normal dan kedua sampel kelompok mempunyai varians yang sama (homogen), maka langkah selanjutnya dilakukan uji hipotesis. Dalam pengujian hipotesis penelitian ini akan diuji dengan menggunakan analisis regresi linier sederhana dan analisis korelasi. Dari hasil perhitungan diperoleh persamaan regresi $Y=62.1621+15.7094 X$. Berdasarkan persamaan regresi tersebut diperoleh nilai kemampuan akhir pada kemampuan berpikir kritis matematis siswa di kelas eksperimen $(X=1)$ dengan rata-rata 77.871 dan kemampuan akhir di kelas control $(X=0)$ dengan rata-rata 62.162. Selanjutnya untuk menguji kelinieran dan keberartian (signifikansi) regresi, dapat dilihat tabel Analisis Varians berikut ini:

Tabel 6. Analisis Varians Untuk Uji Kelinieran dan Keberartian Regresi

\begin{tabular}{cccccc}
\hline Sumber Variasi & Dk & JK & RJK & $F_{\text {hitung }}$ & Ftabel \\
\hline Total & 74 & 382695.31 & - & - & - \\
Regresi (a) & 1 & 142972.97 & 142972.97 & & \\
Regresi (bIa) & 1 & 4565.544 & 4565.544 & 21.408 & 3.97 \\
Sisa & 72 & 15354.747 & 213.260 & & \\
Tuna cocok & 9 & 0.017 & 0.0019 & 7.75 & 2.03 \\
Galat & 63 & 15354.730 & 243.73 & & \\
\hline
\end{tabular}

Berdasarkan tabel di atas untuk menguji hipotesis kelinieran regresi diperoleh nilai $\mathrm{F}_{\text {tabel }}=2.03$ dengan dk pembilang $=\mathrm{k}-2=9 \mathrm{dan} \mathrm{dk}$ penyebut $=$ $n-2=63$. Karena $F_{\text {hitung }}>F_{\text {tabel }}$ maka $\mathrm{H}_{0}$ diterima dan Ha ditolak yang berarti bahwa bentuk regresi linier. Untuk menguji hipotesis keberartian regresi diperoleh $\mathrm{F}_{\text {tabel }}=3.97$ dengan $\mathrm{dk}$ pembilang $=1$ dan $\mathrm{dk}$ penyebut $=\mathrm{n}-2=71$. Karena $F_{\text {hitung }}>\mathrm{F}_{\text {tabel }}$ maka $\mathrm{H}_{0}$ ditolak dan Ha diterima yang berarti koefisien 
arah regresi nyata sifatnya sehingga regresi yang diperoleh berarti (signifikan).

Telah dibuktikan bahwa bentuk hubungan antara peubah respon $Y$ (kemampuan berpikir kritis matematis) dan peubah predictor $X$ (model Creative Problem Solving) memang linier dan berarti (signifikan). Dengan demikian analisis korelasi dapat digunakan untuk mengetahui kekuatan hubungan dan besar pengaruh model Creative Problem Solving terhadap kemampuan berpikir kritis matematis siswa.

Berdasarkan hasil perhitungan koefisien korelasi dengan menggunakan rumus product moment diperoleh koefisien korelasi $(\mathrm{r})=0.479$ artinya model pembelajaran Creative Problem Solving (CPS) mempunyai hubungan yang cukup kuat terhadap kemampuan berpikir kritis matematis siswa, dan terdapat pengaruh model pembelajaran Creative Problem Solving (CPS) terhadap kemampuan berpikir kritis matematis siswa pada materi relasi dan fungsi sebesar $23 \%$.

Setelah koefisien korelasi dan koefisien determinasi diperolah, selanjutnya dilakukan pengujian koefisien korelasi untuk mengetahui apakah korelasi yang telah diperoleh ada artinya atau tidak. Berdasarkan perhitungan uji keberartian korelasi, diperoleh tabel $=1.99$ dengan $\mathrm{dk}=\mathrm{n}-2=72$. Dengan demikian thitung $(=4.599)>t_{\text {tabel }}(=1.99)$ maka $\mathrm{H}_{0}$ ditolak dan $\mathrm{H}_{a}$ diterima yang artinya kemampuan berpikir kritis matematis siswa dapat dipengaruhi oleh model pembelajaran Creative Problem Solving (CPS).

Selain itu, untuk memperkuat hasil uji hipotesis dalam penelitian ini maka dilakukan analisis respon siswa terhadap model pembelajaran Creative Problem Solving (CPS) dengan menggunakan angket. Berdasarkan hasil analisis respon siswa terhdap model pembelajaran Creative Problem Solving (CPS) dapat disimpulkan bahwa respon siswa sangat positif terhadap model pembelajaran Creative Problem Solving (CPS) karena persentase respon siswa yang menyatakan persetujuan yaitu $95.62 \%$ lebih besar daripada persentase respon yang menyatakan ketidaksetujuan yaitu 4.38 \% sehingga rata-rata

Cartesius: Jurnal Pendidikan Matematika Vol. 1, No. 1

CProdi Pendidikan Matematika Universitas Katolik Santo Thomas 
persentase respon persetujuan siswa terhadap model pembelajaran Creative Problem Solving (CPS) $\geq 85 \%$.

Hasil yang diperoleh dalam penelitian ini menunjukkan bahwa terdapat pengaruh model pembelajaran Creative Problem Solving (CPS) terhadap kemampuan berpikir kritis matematis siswa dan respon siswa sangat positif terhadap model pembelajaran Creative Problem Solving (CPS) yang mana dalam hal ini berarti siswa merasa senang dan suka belajar menggunakan model pembelajaran Creative Problem Solving (CPS).

\section{KESIMPULAN}

Berdasarkan hasil penelitian diperoleh kesimpulan sebagai berikut:

1. Berdasarkan perhitungan koefisien korelasi dengan menggunakan rumus product moment diperoleh koefisien korelasi $(\mathrm{r})=0.479$ artinya model pembelajaran Creative Problem Solving (CPS) mempunyai hubungan yang cukup kuat terhadap kemampuan berpikir kritis matematis siswa, dan terdapat pengaruh model pembelajaran Creative Problem Solving (CPS) terhadap kemampuan berpikir kritis matematis siswa pada materi relasi dan fungsi sebesar $23 \%$ selebihnya dipengaruhi oleh faktor lain.

2. Berdasarkan hasil analisis respon siswa terhadap model pembelajaran Creative Problem Solving (CPS) dapat disimpulkan bahwa respon siswa sangat positif terhadap model pembelajaran Creative Problem Solving (CPS) karena persentase respon siswa yang menyatakan persetujuan yaitu 95.62 $\%$ lebih besar daripada persentase respon yang menyatakan ketidaksetujuan yaitu $4.38 \%$ sehingga rata-rata persentase respon siswa terhadap model pembelajaran Creative Problem Solving (CPS) $\geq 85 \%$.

\section{UCAPAN TERIMAKASIH}

Penulis menyampaikan terimakasih kepada Ibu Sinta Dameria Simanjuntak, S.Si., M.Pd. sebagai dosen pembimbing 1 dan Ibu Frida Marta Argareta Simorangkir, S.Si., M.Pd. sebagai dosen pembimbing 2 yang telah mengarahkan dan membimbing penulis mulai dari awal penelitian hingga berakhirnya penelitian sehingga penulis dapat menuliskan artikel ini yang merupakan bagian dari hasil penelitian penulis. Penulis juga menyampaikan terimakasih kepada kepala program studi Pendidikan Matematika, dekan,

Cartesius: Jurnal Pendidikan Matematika Vol. 1, No. 1

CProdi Pendidikan Matematika Universitas Katolik Santo Thomas 
dan rektor Universitas Katolik Santo Thomas atas dukungan yang diberikan kepada penulis.

\section{DAFTAR PUSTAKA}

[1] Kemendikbud, "Undang-Undang Republik Indonesia Nomor 20 Tahun 2003 Tentang Sistem Pendidikan Nasional," 2003.

[2] P. Pangestu and A. U. P. Santi, "Pengaruh Pendidikan Matematika Realistik Terhadap Suasana Pembelajaran Yang Menyenangkan Pada Pelajaran Matematika Sekolah Dasar," Fibonacci J. Pendidkan Mat. dan Mat., vol. 2, no. 2, pp. 58-71, 2006.

[3] M. Nasional Pendidikan, "Peraturan Menteri Pendidikan Nasional Republik Indonesia No. 22 Tahun 2006," 2006.

[4] O. A. Early, E. R. Winarti, and Supriyono, "Analisis Kemampuan Berpikir Kritis Matematis Ditinjau dari Kemandirian Siswa Kelas VIII melalui Pembelajaran Model PBL Pendekatan Saintifik Berbantuan Fun Pict," Prism. Pros. Semin. Nas. Mat., vol. 1, pp. 388-399, 2018.

[5] F. S. Pratama, Peningkatan Kemampuan Berpikir Kritis dan Pemecahan Masalah Matematika Dengan Problem Posing Pada Siswa Kelas VIII Semester II SMP Muhammadiyah 6 Surakarta Tahun 2014/2015. 2015.

[6] Hasratuddin, "Meningkatkan Kemampuan Berpikir Kritis Siswa SMP Melalui Pendekatan Matematika Realistik," J. Pendidik. Mat., vol. 4, no. 2, pp. 19-33, 2010.

[7] S. D. S. Pradana, Parno, and S. K. Handayanto, "Pengambangan Tes Kemampuan Berpikir Kritis Pada Materi Optik Geometri Untuk Mahasiswa Fisika," J. Penelit. dan Eval. Pendidik., vol. 21, no. 1, pp. 51-64, 2017.

[8] K. E. Lestari, “Implementasi Brain-Based Learning Untuk Meningkatkan Kemampuan Koneksi dan Kemampuan Berpikir Kritis Serta Motivasi Belajar Siswa SMP," J. Pendidik. UNSIKA, vol. 2, no. November, pp. 3646, 2014.

[9] V. Purnamasari, "Penerapan Model CPS )Creative Problem Solving) Terhadap Self Concept dan Kemampuan Memecahkan Masalah Siswa Kelas V," Empati J. Bimbing. dan Konseling, vol. 3, no. 3, pp. 56-64, 2016.

[10]M. T. B., “Efektivitas Model Pembelajaran Creative Problem Solving (CPS) Dalam Meningkatkan Hasil Belajar Siswa Pada Materi Limit Fungsi Aljabar," Delta-Pi J. Mat. dan Pendidik. Mat., vol. 1, no. 2, pp. 3142, 2012.

Cartesius: Jurnal Pendidikan Matematika Vol. 1, No. 1

CProdi Pendidikan Matematika Universitas Katolik Santo Thomas 